\title{
Strength Behavior of Cement Mortar Assimilating Rice Husk Ash
}

\author{
Muhammad Harunur Rashid
}

\begin{abstract}
This investigational study was arranged to measure the effect of Rice Husk Ash on strength of cement mortar. Mortar samples were made with a diversity of replacement levels of the cement by mass: $0,10,15,20$ and $30 \%$ for rice husk ash. Samples were stored up to 28 days confirming ASTM standards. After this time the samples were stored in a space without controlling the ambient environment up to 350 days. Setting time is changed due to the RHA addition in mortar. The initial setting time is prolonged; however the final setting time is reverse in nature due to the addition of RHA in mortar for all replacement level. Compressive strength is found out at 7, 28, 90 and 350 days age. Test results showed that strength increases with the rice husk ash of 15 and 20\% OPC replacement level and on ward 90 days ages. In this study it is concluded that the optimum replacement level of ordinary Portland cement by rice husk ash might be 15 or $20 \%$ by considering other parameters.
\end{abstract}

Keyword---Compressive Strength, Rice Husk Ash, Grinding Time, Setting Time, Mortar.

\section{INTRODUCTION}

Researchers are always trying to introduce new materials in cement to make it economical and improve the quality. New materials with pozzolanic and cementitious properties have been investigated to mix with cement during the past years (Neville, 1995; Mehta, 1983) for technical and economic reasons. Among these materials some are industrial and agricultural waste by-products and some are naturally active materials. Different materials with pozzolanic properties such as blast furnace slag, silica fume, fly ash, and rice husk ash have played an important role in the production of cement mortar/concrete. According to Graciela et al. (2009) among the different existing residues and by-products, the possibility of using Rice Husk Ash (RHA) has attracted more attention to researchers than other crop residues. The production of paddy rice is close to 747 million tons globally in the year of 2013, where Asian countries comprise nearly 91\%. In fact, Bangladesh is holding the forth position in all over the world and per capita rice consumption is higher than any other countries. In Bangladesh there are so many small rice mills, where rice husk is burned in uncontrolled manner. After burning a huge amount of rice husk ash is produced and dumped it as waste which creates an environmental problem.

Muhammad Harunur Rashid, Department of Civil Engineering, Khulna University of Engineering \& Technology, Email: hafin02@gmail.com
Rice husks are the natural sheaths that form on rice grains during their growth. At the time of refining rice, the husks which come out from this process usually have no commercial interest.Most of the husk from the rice milling industry is either burnt or dumped as waste in open fields and a small amount is used as fuel for boilers, electricity generation, etc. (RHA market study, 2003). Paddy on an average consists of $72 \%$ of rice, 5 - $8 \%$ of bran, and $20-22 \%$ of husk, on weight basis (Ou, et al., 2007; Basha, et al., 2005; Bouzoubaa and Fournier, 2001; Prasad, et al., 2000). This husk contains about 75 - $80 \%$ organic volatile matter and the balance 20 - $25 \%$ of the weight of this husk is converted into ash during the firing process, is known as rice husk ash (RHA). This RHA usually contains around 85\% - 97\% amorphous silica with small amount of alkalis and other trace elements (Ou, et al., 2007; Basha, et al., 2005; Bui, et al., 2005; Asavapisit and Ruengrit, 2005; Adylov, et al., 2003; Bouzoubaa and Fournier, 2001; Saha, et al., 2001; Prasad, et al., 2000; Natio, 1999). This silica in the ash undergoes structural transformations depends on conditions (time and temperature) of combustion.

According to Sugita (1993) and Joseph et al. (1989), amorphous ash is formed at incineration temperature of 550 to $800^{\circ} \mathrm{C}$ and the change occurs from amorphous to crystalline form at approximately 800 to $900^{\circ} \mathrm{C}$. Some other researchers reported that RHA produced below $700^{\circ} \mathrm{C}$ would be in amorphousform and above $800^{\circ} \mathrm{C}$ would result in crystalline form (Nair, et al., 2008; Nair, et al., 2006; Khurama and Khurama, 2003; Maeda, et al., 2001; Bouzoubaa and Fournier, 2001; Mehta, 1979).Tendency of formation of crystalline material was observed by Spence and Cook (1983) at or above $600^{\circ} \mathrm{C}-700^{\circ} \mathrm{C}$ firing temperature for RHA. In another study (Cook, 1980), it was found that the optimum firing temperature for rice husk ash is varied from 500 to $750^{\circ} \mathrm{C}$. The favourable structures and properties of RHA can vary by the burning process. In other words, to some extent, the structure and properties of RHA have to be dependent on the burning temperature. James and Rao (1986) indicated that isothermal heating at a minimum of $402^{\circ} \mathrm{C}$ is required for completing destruction of organic matter from rice husk and to liberate silica.The incinerating conditions essentially control the quality of ash (Nair, et al., 2006; Bui, et al., 2005; Shomglin, et al., 2001; Maeda, et al., 2001; Mehta, 1979; Yoeh, et al.,1979), which may either be in crystalline or amorphous form. Geographic location can also affect the ash properties such as fineness and colour (Prasad, et al., 2000; Bouzoubaa and Fournier, 2001; Bui, et al., 2005). The RHA in amorphous state can exhibit active pozzolanicity under 
normal conditions (Nair, et al., 2006; Shomglin, et al., 2001; Maeda, et al., 2001; Moayad and Hana, 1984; Mehta, 1979).Nair et al. (2008) stated that not only the temperature ranges, but also the duration of incineration controls the ash quality. In principle, higher temperature-short duration or lower temperature-long duration will result in amorphous ash.

Different studies showed that some percentage of cement replaced by RHA indicate excellent performance when compared to control concrete (Sensale, 2006; Zhang, et al., 1996; Zhang and malhotra, 1996; Mehta, 1994; James, et al., 1986; Mehta and Pitt, 1977). Available literature showed that most of the researches have been conducted by producing RHA through controlled combustion process. However, the RHA that is produced in Bangladesh throughout uncontrolled burning in rice husking mills. To find out the use of RHA as cement replacing material in mortar, samples were prepared with different replacement level of Ordinary Portland Cement (OPC) by Rice Husk Ash (RHA) obtained from uncontrolled manner.

\section{EXPERIMENTAL PROCEDURE}

\section{A. Material}

The objective of the experimental program was to investigate the strength properties of cement mortar in presence of RHA as a supplementary material of OPC. The materials used were Ordinary Portland cement (OPC) complying with ASTM Type I, ASTM graded sand as fine aggregate and RHA obtained from laboratory combustion process, which is reasonably comparable to traditional uncontrolled combustion process available in rural Bangladesh.

The rice husk was collected at peak time (NovemberDecember) of paddy harvesting in Bangladesh. The collected rice husk contains 7 to $11 \%$ of moisture, was kept in sunny place for two days prior burning to remove the moisture from it and this process is relatively similar to the field burning condition of rural Bangladesh. After drying, the moisture content in the husk was observed to be 0.65 to $1.90 \%$.

\section{B. RHA Production}

The rice husk ash produced at laboratory incineration system, which was very close to the rural incineration system. A rectangular enclosure of $2.05 \mathrm{~m}$ long and $0.9 \mathrm{~m}$ wide was divided into ignition and ash retention chamber separated by a steel wire mesh of $5 \mathrm{~mm}$ square opening. The ignition chamber was $0.65 \mathrm{~m}$ wide and $0.6 \mathrm{~m}$ deep and that of the retention chamber was $0.4 \mathrm{~m}$ and $0.4 \mathrm{~m}$ respectively. The detailed of this chamber is shown in Figure 1. The produced ash is deposited at the retention chamber and was kept for 60 hours without any disturbance. Feeding of Rice Husk in this ignition system was slow in comparison to the existing system of Bangladesh.
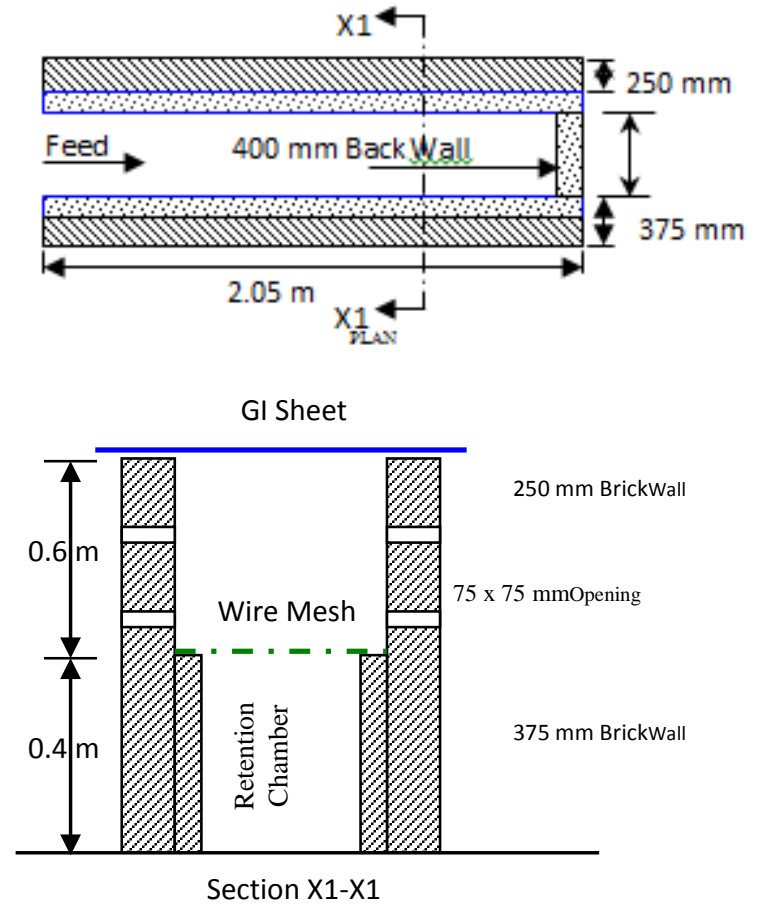

Fig. 1: Incineration System

\section{Temperature History}

Temperature history of rice husk incinerations is presented for laboratory burning system in Figure 2. The typical firing temperature was $647^{\circ} \mathrm{C}$ and the extreme high and low temperature at that period was $718^{\circ} \mathrm{C}$ and $533^{\circ} \mathrm{C}$ respectively. Temperatures at ignition chamber are the average of three different points plotted in Figure 2 (a). Temperatures were collected at regular interval of 30 minutes. The average temperature of ignition and accumulation chamber were termed as firing and cooling temperature and plotted in Figure 2 (a) and (b) respectively.

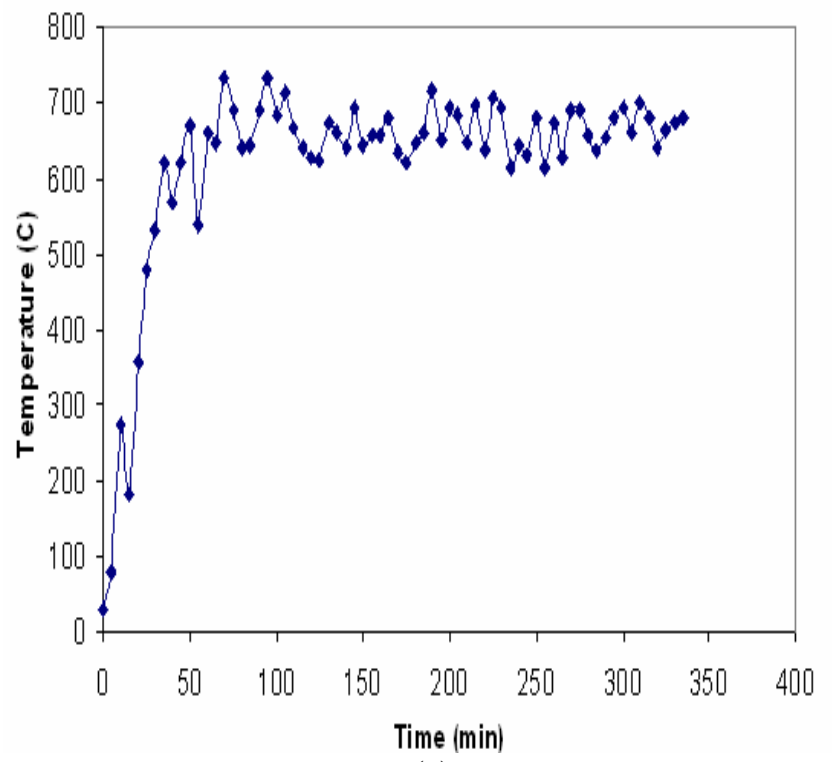

(a) 


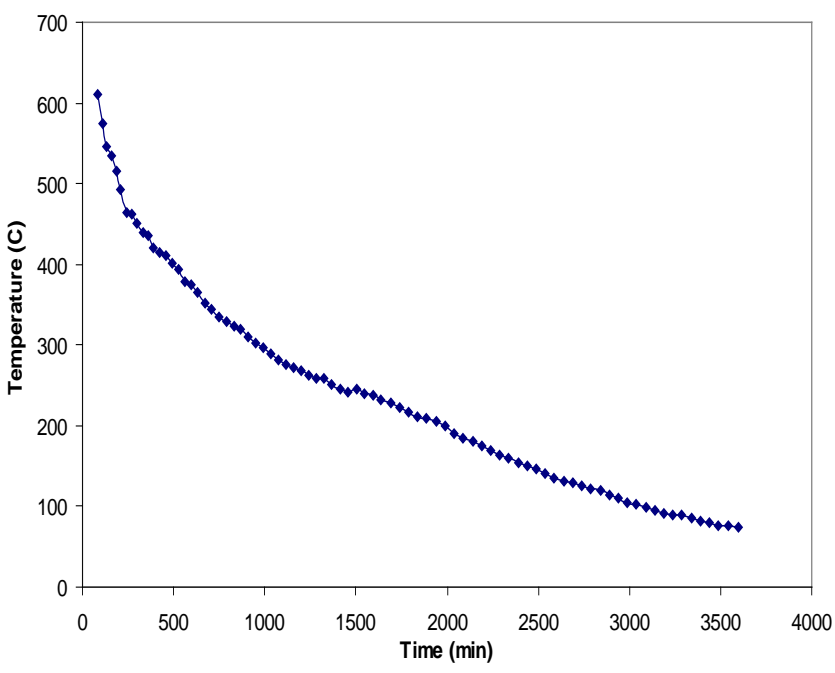

(b)

Fig. 2 Temperature variation at (a) ignition and (b) cooling chamber with respect to time

Temperature was sharply dropped at a rate of $32.65^{\circ} \mathrm{C} / \mathrm{h}$ within the initial four hours and after that cooling became slower. The average ash temperature at 60 hours was observed to be $69.8^{\circ} \mathrm{C}$ which was much higher than the ambient temperature of $26^{\circ} \mathrm{C}$.

\section{Fineness of RHA}

Retention and grinding time effect on RHA fineness. Blaine fineness was measured after sieved the ash through sieve No. 200. The result is shown in Table 1 . The results showed an insignificant effect of grinding time on the amount of ash passing through the sieve No. 200.

TABLE I

FINENESS OF RICE HUSK ASH ON GRINDING AND RETENTION TIME

\begin{tabular}{|c|c|c|c|c|}
\hline \multirow{2}{*}{$\begin{array}{c}\text { Retention } \\
\text { time } \\
\text { (hours) }\end{array}$} & $\begin{array}{c}\text { Grinding } \\
\text { Time } \\
\text { (minutes) }\end{array}$ & $\begin{array}{c}\% \\
\text { Passing }\end{array}$ & \multicolumn{2}{|c|}{ Blaine fineness } \\
\hline \multirow{3}{*}{60} & 45 & 51.73 & 5773 & $\begin{array}{c}\text { \% wrt. 90 minutes } \\
\text { grinding }\end{array}$ \\
\cline { 2 - 5 } & 90 & 50.62 & 6129 & -5.8 \\
\cline { 2 - 5 } & 135 & 52.49 & 6302 & 0.0 \\
\hline
\end{tabular}

The collected ash was whitish in color which indicates of complete oxidation of the carbon in the ash [1]. Blackish color indicates the partial burning of the rice husk and generally unburn carbon was present in the ash.

\section{E. Chemical composition of RHA}

The chemical composition of RHA used in this work is shown in Table 2.

\section{F. Mixing}

The mix proportion of cement mortar is $1: 2.75$ by weight of material for all samples. Controlled sample is of zero percent of RHA and is designated by A0. Other samples were mixed in different proportions of RHA with OPC cement i.e. OPC cement was partially replaced by RHA. Detail mixtures of mortar with sample ID are shown in Table3.
TABLE II

CHEMICAL COMPOSITION OF RICE HUSK ASH

\begin{tabular}{|c|c|}
\hline Constituents & \%Composition \\
\hline $\mathrm{Fe}_{2} \mathrm{O}_{3}$ & 1.28 \\
\hline $\mathrm{SiO}_{2}$ & 89.86 \\
\hline $\mathrm{Al}_{2} \mathrm{O}_{3}$ & 0.73 \\
\hline $\mathrm{CaO}$ & 0.91 \\
\hline $\mathrm{MgO}$ & 1.16 \\
\hline L.O.I. & 4.26 \\
\hline
\end{tabular}

TABLE III

Mixing PROPORTION For PREPARATION OF MORTAR

\begin{tabular}{|l|c|c|c|c|c|}
\hline Mix ID & A0 & A10 & A15 & A20 & A30 \\
\hline$\%$ of OPC & 100 & 90 & 85 & 80 & 70 \\
\hline$\%$ of RHA & 0 & 10 & 15 & 20 & 30 \\
\hline
\end{tabular}

\section{G. Sample Preparation and Testing}

Cubical specimen of $5 \mathrm{~cm} \times 5 \mathrm{~cm} \times 5 \mathrm{~cm}$ sizes were prepared in a controlled environment, where temperature was maintained at $23 \pm 3^{\circ} \mathrm{C}$. Basic mixing ratio is one part of Ordinary Portland Cement and 2.75 parts of ASTM standard sand proportioned by weight. After that the OPC was replaced by rice husk ash at 10, 15, 20 and 30 percent by weight. For all the mixtures water cement ratio was previously fixed by flow table test and confirming a flow value of $110 \pm 5 \mathrm{~mm}$ in 25 drops. The samples were compacted in two layers according to the ASTM C109 and demolded after one day of casting, at this time the samples are covered by plastic sheet and then immersed in lime water for a maximum of 28 days. After this the samples were removed and stored in ambient/normal weather where temperature variation was 11 to $42^{\circ} \mathrm{C}$. The relative humidity also varied from 35 to $90 \%$ in a year.

\section{Result AND Discussion}

\section{A. Water Demand}

Water demand was observed from the result of flow table test that the water demand is increased by $103 \%$ and $112 \% 12 \%$ for $10 \%$ and $30 \%$ cement replacement level respectively, and this demand pattern is increasing for increased of RHA addition. This is due to the high fineness and porous surface of RHA. The result is similar to the previous study (S. Rukzon, et. Al. 2009; R. Sumrernget. Al. 2006). The result is plotted in Fig. 3.

\section{B. Setting Time}

Initial and final setting time was examined using the manually operated Vicat apparatus according to ASTM C191 to observe the effect of rice husk ash addition with Ordinary Portland Cement.These methods determine the time of setting of hydraulic cement by means of the Vicat needle. The results of all penetration tests were recorded and the time for penetration of $25 \mathrm{~mm}$ is determined by interpolation. This is the initial setting time. The final setting time is when the needle does not sink visibly into the paste. This process was done on pure cement paste and cement paste having $10 \%$, 
$15 \%, 20 \%$ and $30 \%$ RHA by replacing the same amount of cement by weight. Finally, the effect of RHA addition in cement on setting time was found out and plotted in Figure3.

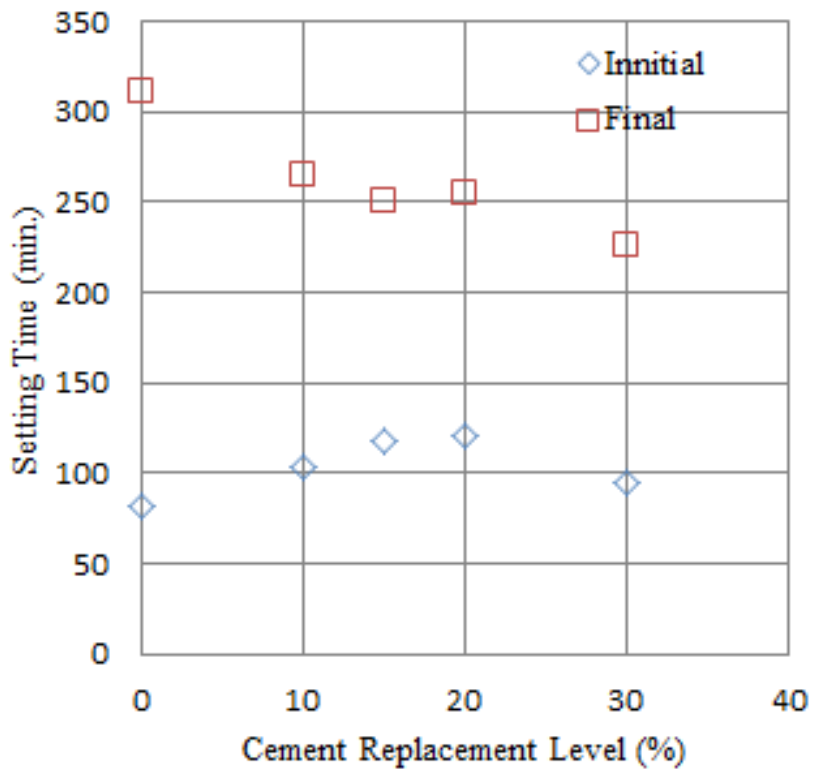

Fig. 3 Setting time with cement replacement level

\section{Compressive Strengt}

One of the most important properties of cementitious materials is its compressive strength. Numerous researchers has been tried to utilize Rice Husk Ash as a cement replacing material. Most of the RHA used previously were collect or manufactured from controlled combustion system. Zhang and malhotra (1996), Ismail and Waliuddin (1996) were tried to investigate the effect of RHA addition in concrete as partial replacement of cement on compressive strength and observed a good relation between the strength and replacement levels. The compressive strengths of the prepared samples with different Rice Husk Ash are given in next. The compressive strength was tested at 7, 28, 90 and 350 days.

The strength of mortar specimen prepared from Ordinary Portland Cement (OPC), RHA and ASTM Standard Sand are given in Table 4.

It is observed from Table 4 that at 7 days the maximum strength for sample having RHA is observed 79.83 percent of the controlled sample strength for 15\% replacement levels and at 28 days that is 93.41 percent of the controlled sample for the same replacement levels. At 90 days the controlled sample exhibits lower strength than the sample having 20\% RHA. At this age the maximum strength was observed at $20 \%$ replacement levels and $105.34 \%$ higher than the controlled sample. At 350 days the samples having RHA still in increasing rate, however, this rate is slow compared to the controlled sample. At this age sample having $15 \%$ and $20 \%$ replacement levels shows higher compressive strength compared to the controlled sample.

Figure 4 is described the compressive strength of all samples compared to the controlled sample. Controlled samples at different ages are presented as 100 percent. In this Figure it is observed that at 7 and 28 days strength the controlled sample shows higher strength values than the samples having RHA in different percentages. At 90 days ages sample up to $20 \%$ replacement levels of OPC by RHA shows higher compressive strength compared to the controlled sample. At 350 days the compressive strength having $15 \%$ and $20 \%$ RHA exhibits higher values than the controlled sample. This observation is quite similar to Feng et.al. (2003). According to the finding on compressive strength of RHA concrete by Feng et.al. (2003), the mixture with $20 \%$ rice husk ash and $\mathrm{w} / \mathrm{b}$ ratio $=0.50$ showed compressive strength values equal to the reference mixture

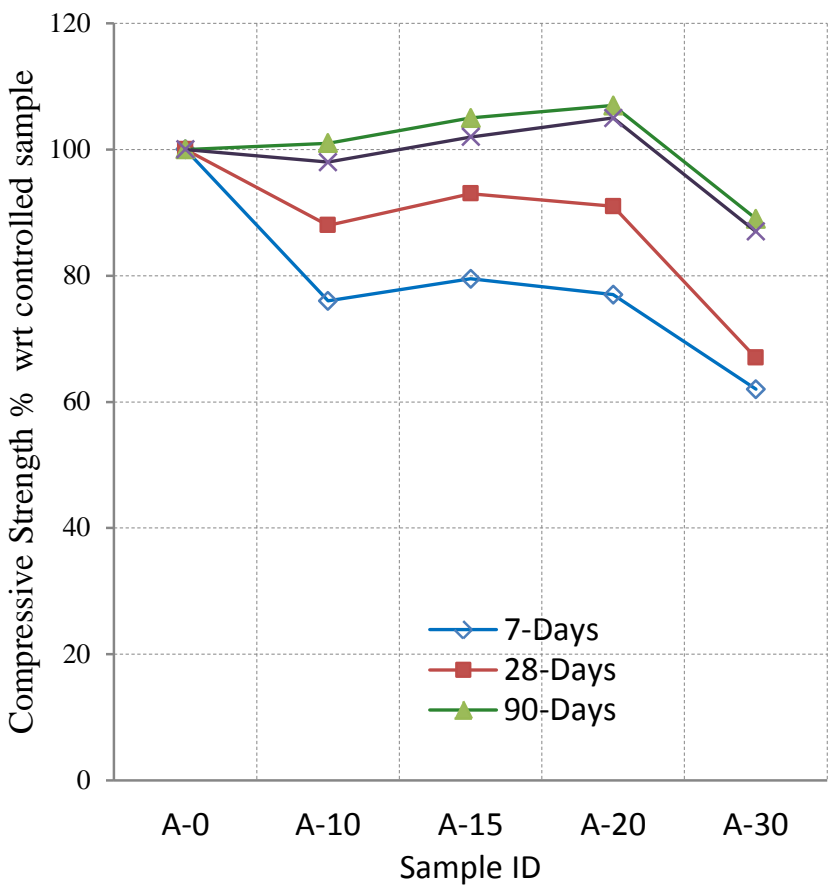

Fig. 4 Percentage of strength with respect to controlled specimen at different ages

(REF) at 7 days and at later ages of 28 and 91 days the compressive strength values were higher than those of the reference mixture. Mahmud et al. (1996) reported 15\% cement replacement by RHA as anoptimal level for achieving maximum strength. Zhang et al. (1996) suggested 10\% RHA replacement exhibited higher strength than control OPC at all ages. Ganesan et al. (2008) concluded that concrete containing $15 \%$ of RHA showed highest compressive strength. Dakroury et al. (2008) reported that using 30\% RHA as a replacement of part of cement could be considered optimum for all content of $\mathrm{W} / \mathrm{C}$ ratios in investigated mortars because of its high value of compressive strength. Replacement of OPC in mortar by RHA at 15 and 20\% shows better result than the controlled sample. 
TABLE IV

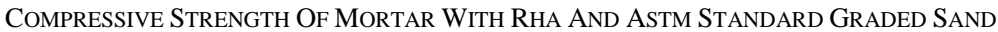

\begin{tabular}{|c|c|c|c|c|c|c|c|c|c|c|c|c|}
\hline \multirow{3}{*}{$\begin{array}{l}\text { 光 } \\
\text { 音 } \\
\text { 岕 }\end{array}$} & \multicolumn{12}{|c|}{ Strength, N/mm ${ }^{2}$} \\
\hline & \multicolumn{3}{|c|}{7 Days } & \multicolumn{3}{|l|}{28 Days } & \multicolumn{3}{|l|}{90 Days } & \multicolumn{3}{|l|}{350 Days } \\
\hline & 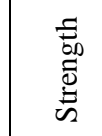 & 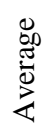 & 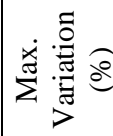 & 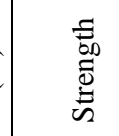 & 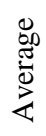 & 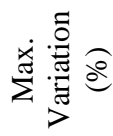 & 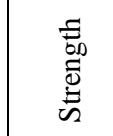 & 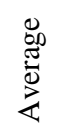 & 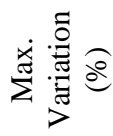 & 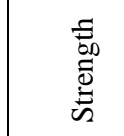 & $\begin{array}{l}\stackrel{0}{00} \\
\frac{0}{0} \\
\stackrel{4}{4}\end{array}$ & 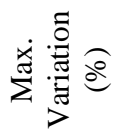 \\
\hline A- 0 & $\begin{array}{l}26.68 \\
27.05 \\
24.75\end{array}$ & $\begin{array}{l}0 \\
\stackrel{0}{\omega} \\
\text {. }\end{array}$ & $\begin{array}{l}\text { ○ी } \\
\infty\end{array}$ & $\begin{array}{l}34.27 \\
33.20 \\
31.58\end{array}$ & $\begin{array}{l}\text { oै } \\
\text { mे }\end{array}$ & 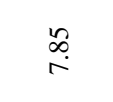 & $\begin{array}{l}38.35 \\
36.61 \\
34.51\end{array}$ & $\begin{array}{l}\text { I } \\
\dot{0} \\
\dot{m}\end{array}$ & $\begin{array}{l}\tilde{0} \\
0 \\
0\end{array}$ & $\begin{array}{l}40.09 \\
36.30 \\
36.99\end{array}$ & $\begin{array}{l}\stackrel{a}{\hat{n}} \\
\text { m }\end{array}$ & $\stackrel{\stackrel{\rho}{\leftrightarrow}}{\sigma}$ \\
\hline A-10 & $\begin{array}{l}20.51 \\
20.00 \\
19.03\end{array}$ & $\begin{array}{l}\text { மீ } \\
\stackrel{9}{\rightarrow}\end{array}$ & $\underset{N}{N}$ & $\begin{array}{l}30.13 \\
28.88 \\
27.70\end{array}$ & $\begin{array}{l}\text { \& } \\
\infty \\
\text { ஸे }\end{array}$ & Oे. & $\begin{array}{l}38.47 \\
37.01 \\
35.06\end{array}$ & $\begin{array}{l}\text { مீ } \\
\dot{\varphi} \\
\dot{\infty}\end{array}$ & $\begin{array}{l}0 \\
\infty \\
\infty\end{array}$ & $\begin{array}{l}39.30 \\
37.48 \\
35.34\end{array}$ & $\begin{array}{l}\hat{m} \\
\hat{m}\end{array}$ & $\begin{array}{l}\infty \\
0 \\
\stackrel{0}{0}\end{array}$ \\
\hline A-15 & $\begin{array}{l}21.93 \\
21.00 \\
19.72\end{array}$ & $\begin{array}{l}\infty \\
\stackrel{\sim}{0} \\
\stackrel{\sim}{0}\end{array}$ & $\begin{array}{l}\infty \\
0 \\
0\end{array}$ & $\begin{array}{l}32.11 \\
30.67 \\
29.74\end{array}$ & 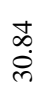 & $\stackrel{\infty}{\stackrel{m}{N}}$ & $\begin{array}{l}37.44 \\
39.95 \\
36.60\end{array}$ & $\begin{array}{l}\text { @़ } \\
\text { ले }\end{array}$ & $\stackrel{J}{\sigma}$ & $\begin{array}{l}40.02 \\
36.68 \\
37.85\end{array}$ & $\begin{array}{l}\infty \\
\stackrel{\infty}{c} \\
\infty \\
\stackrel{m}{m}\end{array}$ & $\begin{array}{l}\stackrel{\infty}{\oplus} \\
\infty\end{array}$ \\
\hline A-20 & $\begin{array}{l}21.51 \\
20.86 \\
19.37\end{array}$ & $\begin{array}{l}\infty \\
\stackrel{\leftrightarrow}{0} \\
\stackrel{\sim}{\sim}\end{array}$ & $\begin{array}{l}\text { வ } \\
\text { の̆ }\end{array}$ & $\begin{array}{l}31.54 \\
29.98 \\
28.37\end{array}$ & $\begin{array}{l}\mathscr{8} \\
\text { নे }\end{array}$ & $\begin{array}{l}\stackrel{2}{0} \\
\stackrel{0}{\circ}\end{array}$ & $\begin{array}{l}36.65 \\
38.82 \\
39.85\end{array}$ & $\begin{array}{l}\mathbb{J} \\
\infty \\
\infty\end{array}$ & $\begin{array}{l}m \\
\infty \\
\infty\end{array}$ & $\begin{array}{l}37.44 \\
41.47 \\
39.02\end{array}$ & $\begin{array}{l}\vec{m} \\
\text { ले }\end{array}$ & $\stackrel{\curvearrowright}{\sigma}$ \\
\hline A-30 & $\begin{array}{l}16.03 \\
16.89 \\
15.34\end{array}$ & $\begin{array}{l}8 \\
0 \\
0\end{array}$ & $\begin{array}{l}\infty \\
\sigma\end{array}$ & $\begin{array}{l}22.93 \\
21.82 \\
21.03\end{array}$ & $\begin{array}{l}\text { Oे } \\
\text { ते }\end{array}$ & $\begin{array}{l}\text { mె } \\
\infty\end{array}$ & $\begin{array}{l}34.56 \\
31.13 \\
31.85\end{array}$ & $\begin{array}{l}\tilde{i n} \\
\text { } \\
\text { ñ }\end{array}$ & హे & $\begin{array}{l}31.49 \\
34.65 \\
31.58\end{array}$ & $\begin{array}{l}\hat{\omega} \\
\text { } \\
\text { mे }\end{array}$ & $\stackrel{7}{\circ}$ \\
\hline
\end{tabular}

\section{CONCLUSION}

Base on above results, the following conclusions can be drawn.

Grinding time of 90 minutes is reasonably satisfactory for optimum fineness of rice husk ash produced in laboratory burning with 60 hours retention time.

The addition of RHA increases the initial setting time of cement mortar. On the other hand, the final setting time of cement mortar gradually decreases due to the addition of RHA.

The compressive strength of control sample exhibits higher values up to 28 days age than all other samples having RHA.

The compressive strength of mortar at 15 and 20\% replacement is almost same at the highest age. The optimum replacement level of ordinary Portland cement by rice husk ash might be 15 or $20 \%$ by considering other parameters.

\section{REFERENCES}

[1] Anwar, M., Miyagawa, T., and Gaweesh, M. "Using rice husk ash as a cement replacement material in concrete". In the Proceedings of the 2001 first international Ecological Building Structure Conference. 2001; pp. 671- 684.

[2] A Tashima, M.M., Silva, C.A.R., Akasaki, J.L., and Barbosa, M.B. 'The Possibility of Adding the Rice Husk Ash (RHA) to the Concrete'. In the Proceedings of the 2004 International RILEM Conference on the Use of Recycled Materials in Building and Structures. 2004; pp. 778 - 786.

[3] Chindaprasirt, P., and S.Rukzon, "Strength, porosity and corrosion resistance of ternary blend Portland cement, rice husk ash and fly ash mortar”, Construction and Building Materials. 22(8):2008; pp 16011606.

http://dx.doi.org/10.1016/j.conbuildmat.2007.06.010

[4] Chindaprasirta, P., P. Kanchandaa, A.Sathonsaowaphaka, and H.T. Caob, "Sulfate resistance of blended cements containing fly ash and rice husk ash”, Construction and Building Materials. 21(6): 2007; pp-13561361.

[5] Coutinho, J.S. "The combined benefits of CPF and RHA in improving the durability of concrete structures",Cement and Concrete Composites. 25(1): 2002; pp-51-59.
[6] Dakroury AE and Gasser MS 2008. Rice husk ash (RHA) as cement admixture for immobilization of liquid radioactive waste at different temperatures. Journal of Nuclear Materials. 381(3): 271-277. http://dx.doi.org/10.1016/j.jnucmat.2008.08.026

[7] Della, V.P., I. Kuhn, D. Hotza, "Rice husk ash as an alternate source for active silica production”, Materials Letters. 57(4):2002; pp- 818-821.

[8] Feng, Q., Yamamichi, H., Shoya, M., and Sugita, S. "Study on the pozzolanic properties of rice husk ash by hydrochloric acid pretreatment”. Cement and Concrete Research. 34(3): 2004; pp-521526.

[9] Ganesan K, Rajagopal K and Thangavel K 2008. Rice husk ash blended cement: Assessment of optimal level of replacement for strength and permeability properties of concrete. Construction and Building Materials. 22(8): 1675-1683 http://dx.doi.org/10.1016/j.conbuildmat.2007.06.011

[10] Habeeb, G.A., and Fayyadh, M.M. 'Rice Husk Ash Concrete: the Effect of RHA Average Particle Size on Mechanical Properties and Drying Shrinkage”. Australian Journal of Basic and Applied Sciences. 3(3): 2009; pp-1616-1622.

[11] Mahmud, H.B., Majuar, E., Zain, M.F.M., and Ham id, N.B.A.A. "Mechanical Properties and Durability of High Strength Concrete Containing Rice Husk Ash”. Journal of advanced concrete technology. 79(1): 2009; pp-21-30.

[12] Mahmud HB, Chia BS and Hamid NBAA 1996. Rice husk ash-an alternative material in producing high strength concrete, A. AlManaseer, S. Nagataki, R.C. Joshi (Eds.), Proceedings of International Conference on Engineering Materials vol. II, CSCE/JSCE, Ottawa, Canada: 275-284.

[13] Mehta, P.K. "Rice Husk Ash - A unique supplementary cementing material Proceeding" International Symposium on Advances in Concrete Technology. Editor. Malhotra,V.M. Athens, Greece, 1992; pp407- 430.

[14] R. Sumrerng, P. Chindarprasirt, R. Mahachai,,” Effect of grinding on chemical and physical properties of rice husk ash" International Journal of Minerals, metallurgy and Materials,vol16, number2, 2009, pp 242247.

[15] S. Rukzon, and P. Chindarprasirt, 2006," Strength of tenary blended cement mortar containing Portland cement, rice husk ash and fly ash. J. Eng. Inst. Thailand, 17(2006) p33.

[16] Zhang MH and Malhotra VM 1996. High performance concrete incorporating RHA as supplementary cementing material. ACI Mater J., 93(6): 629-636. 